\section{A New Disease in Limonium latifolium Hybrids. II. Investigating Insect Vectors}

\author{
Phyllis G. Weintraub ${ }^{1}$
}

Department of Entomology, Agricultural Research Organization, Gilat Research Center, D.N. Negev 85280, Israel

Shimon Pivonia

Northern Arava Research and Development, Sapir, D.N. Arava 86825, Israel

Arieh Rosner and Abed Gera

Department of Virology, ARO, The Volcani Center, Bet Dagan 52050, Israel

Additional index words. Orosius orientalis, Circulifer haematoceps, Circulifer tenellus, Exitianus capicola

\begin{abstract}
Symptoms typical of a phytoplasma infection were observed on a large number of Limonium hybrids in Israel in October 2000. Phytoplasma infection was confirmed by electron microscopy and polymerase chain reaction analysis. To identify the agent of pathogen spread surveys were made of candidate leafhoppers vectors in Limonium hybrid crops: one known phytoplasma vector (Orosius orientalis (Matsumura)) was present in very large numbers, $\approx 10$-fold greater than any other species; three other known vectors were present in low to moderate numbers (Circulifer haematoceps complex (Mulsant et Rey), C. tenellus complex (Baker) and Exitianus capicola Stål); individual specimens of other vectors were occasionally found. Field collected specimens of these four species were shown to vector phytoplasma to healthy Limonium hybrid seedlings; this is the first time $E$. capicola has been shown to be a phytoplasma vector. A laboratory colony of $O$. orientalis was additionally shown to be able to acquire the phytoplasma from infected Limonium hybrids and subsequently vector it to healthy seedlings.
\end{abstract}

Two species and two hybrids of Limonium are grown in commercial production in the Arava Valley (located between the Dead Sea and Red Sea); these include Limonium altaica ('Emile'), L. sinuatum (annual statice), L. latifolium $\times L$. caspium ('Beltlaard'), and $L$. latifolium $\times L$. bellidifolium ('Misty', 'Supreme', and 'Sunglow'). In any one year there are a total of $\approx 70$ $h a ; \approx 15$ ha are in $L$. sinuatum production and the remainder in L. altaica and Limonium hybrids. These plants are grown primarily for export to Europe as cut flowers for floral arrangements. Flowers are grown for 1 to 10 years in walk-in tunnels $(7 \times 100 \mathrm{~m})$ covered with plastic; both ends are open and ventilation holes are cut about every $2 \mathrm{~m}$. For the first 15 years of commercial production in the Arava, the crops were not affected by yellows disease. There was little need for pest management as there were no major insect pests, weeds were rogued out by hand, and mildew was treated chemically, when necessary. In October 2000 diseased plants were first observed in the northern Arava and then the disease quickly spread to other areas. Only $L$. latifolium hybrids were observed to be infected. Symptoms included small and/or deformed or discolored flowers; small, narrow basal leaves,

Received for publication 23 June 2003. Accepted for publication 24 Jan. 2004. Contribution from the Institute of Plant Protection, Agricultural Research Organization, No. 518/03. This research was supported in part by a grant from the Chief Scientist, Ministry of Agriculture, State of Israel. We thank Benjamin Raccah for providing access to insects from a 1996 survey of the Arava Valley and Rachel Leveta for technical assistance.

${ }^{1}$ To whom reprint requests should be addressed; e-mail phyllisw@volcani.agri.gov.il. often yellow in color; excessive leaf growth (witches'broom or asparagus fern); and eventual plant death. Over the course of that season up to $60 \%$ of the plants were affected in some areas. Diseased plant tissue was examined by electron microscopy, and the presence of phytoplasma was confirmed. Management practices now include scheduled insecticide treatments in an attempt to control leafhoppers.

Phytoplasmas may be transmitted to healthy plants through the parasitic plant Cuscuta pentagona (dodder), by grafting or vegetative propagation, and, most effectively, by insects. The primary phytoplasma vectors are leafhoppers and planthoppers, although a psyllid has recently been proven to be a vector (Font et al., 1999). The objective of this study was to survey insects and determine the vector(s) of phytoplasma in Limonium hybrids.

\section{Materials and Methods}

Leafhopper survey. Surveys of leafhoppers began in December 2000 by placing yellow sticky traps in the tunnels with Limonium hybrids at three privately owned sites in the region. Yellow sticky traps (Jewnin-Joffe Industry Ltd., Israel) $(14 \times 20 \mathrm{~cm})$ were placed vertically just above the canopy and replaced weekly throughout the year 2001. Leafhoppers were carefully removed from the traps, washed in two changes of technical grade hexanes to remove the glue, sorted to species, and then stored in $95 \% \mathrm{EtOH}$ at room temperature. Samples, 25 to 100 leafhoppers per month (depending on trap catches) were analyzed by polymerase chain reaction (PCR) for the presence of phytoplasma DNA.
PCR and sequence analysis. Because phytoplasmas are phloem-limited, DNA was prepared from leaf midribs and petioles as described by Tanne et al. (2000), and from leafhoppers as described by Maixner et al. (1995). Phytoplasma DNA fragments were amplified using the universal phytoplasma primers P1/P7 (Schneider et al., 1993). The product of the first PCR reaction was further amplified by nested PCR with the r16SF2/r16SR2 and fU3fR5 primer pairs (Lee et al., 1995), and used to amplify 1143,788 , and 722 bp fragments of phytoplasma DNA. The DNA template in all PCR assays was $20 \mathrm{ng}$ in a $50-\mu \mathrm{L}$ assay. Standard PCR conditions were as described in Tanne et al. (2000). Amplified samples were electrophoresed in a $1.2 \%$ agarose gel, stained with $0.5 \mu \mathrm{g} \cdot \mathrm{mL}^{-1}$ ethidium bromide, and photographed under UV illumination (Sambrook et al., 1989). DNA extracted from symptom-free Limonium and naturally infected periwinkles plants served as negative and positive controls, respectively.

Direct transmission studies. Vacuum samples of insects on Limonium hybrids were taken from the canopy, in the morning hours, in April, May, June, and November 2001. Leafhoppers were sorted to species and placed, in groups of two to five insects, on healthy Limonium hybrid seedlings in the laboratory for a minimum of $48 \mathrm{~h}$. Plants were held in an insect-free growth chamber for at least 1 month before being analyzed by PCR for presence of phytoplasma DNA. Plants were symptom-free at the time of analysis.

Phytoplasma acquisition and transmission studies. A colony of Orosius orientalis (Matsumura), the predominant leafhopper found in the survey, had been previously established from individuals collected in another region of Israel and tested negative for the present of phytoplasma DNA by PCR. Subsamples of this colony were removed and PCR analyzed routinely. This phytoplasma-free colony was established and reared on sesame (Sesanum indicum) and common bean (Phaseolus vulgaris) plants. On three separate occasions (in January, April, and May) symptomatic Limonium hybrids were brought to the laboratory. Groups of 20 adult leafhoppers were confined to these plants for a minimum of $3 \mathrm{~d}$, and then transferred to sesame plants for 2 to 4 weeks before groups of 2 to 5 were placed on healthy Limonium hybrid seedlings. Inoculation access Limonium plants were held in an insect-free growth chamber for at least 1 month before being analyzed by PCR for presence of phytoplasma DNA. Plants were symptom-free at the time of analysis.

Table 1. Survey and total number of leafhoppers, known to be phytoplasma or spiroplasma vectors, captured in Limonium hybrid crops from December 2000 to December 2001.

\begin{tabular}{lc}
\hline Species & Total caught (no.) \\
\hline Orosius orientalis & 8279 \\
Circulifer haematoceps & 825 \\
Circulifer tenellus & 832 \\
Exitianus capicola & 883 \\
Austroagallia sinuata & 94 \\
Psammotettix spp. & 32 \\
\hline
\end{tabular}


Table 2. Transmission trials of field-collected leafhopper specimens to healthy Limonium hybrid seedlings and confirmation of infection by PCR.

\begin{tabular}{llcc}
\hline Species & Date & $\begin{array}{c}\text { Test plants } \\
\text { (no.) }\end{array}$ & $\begin{array}{c}\text { Plants positive for } \\
\text { phytoplasma (no.) }\end{array}$ \\
\hline Orosius orientalis & 2 Apr. & 6 & 6 \\
& 23 May & 2 & 0 \\
& 11 June & 1 & 1 \\
& 4 Nov. & 5 & 4 \\
Circulifer haematoceps & 19 Nov. & 8 & 8 \\
Circulifer tenellus & 24 Apr. & 6 & 6 \\
& 21 May & 4 & 3 \\
Exitanus capicola & 24 Apr. & 6 & 6 \\
& 21 May & 3 & 2 \\
Psammotettix sp. & 21 May & 1 & 0 \\
& 3 June & 1 & 0 \\
& 11 June & 1 & 1 \\
\hline
\end{tabular}

Table 3. Acquisition of phytoplasma from phytoplasma-infected Limonium plants and transmission to healthy plants by Orosius orientalis.

\begin{tabular}{lcc}
\hline $\begin{array}{l}\text { Month } \\
\text { removed } \\
\text { from field }\end{array}$ & $\begin{array}{c}\text { Test } \\
\text { plants } \\
\text { (no.) }\end{array}$ & $\begin{array}{c}\text { Plants positive } \\
\text { for phytoplasma } \\
\text { (no.) }\end{array}$ \\
\hline January & 6 & 6 \\
April & 6 & 5 \\
May & 1 & 1 \\
\hline
\end{tabular}

\section{Results}

Leafhopper survey. Six known leafhopper vectors of phytoplasmas or spiroplasmas were captured on sticky traps during the course of the survey (Table 1); no planthopper species were caught. Few leafhoppers were caught in July and August. Because of their vector status and abundance, samples of $O$. orientalis, Circulifer haematoceps (Mulsant et Rey) and C. tenellus (Baker) were analyzed by PCR for the presence of phytoplasma DNA. About $73 \%$ of the $O$. orientalis tested positive for phytoplasma and $\approx 50 \%$ of the Circulifer spp. tested positive.

Transmission studies. Results from confining field-collected leafhopper species on healthy Limonium hybrid seedlings are shown in Table 2 . The number of plants used in transmission trials was proportional to the number of candidate species captured. All species except Exitianus capicola Stål successfully vectored phytoplasma to $85 \%$ to $90 \%$ of the plants tested; E. capicola only transmitted phytoplasma to $33 \%$ of test $\mathrm{Li}$ monium. There was no apparent seasonal effect; there was no apparent difference in the ability of insects collected in the spring or fall to vector phytoplasma. Phytoplasma-free $O$. orientalis were able to acquire phytoplasma from infected plants and subsequently transmit the pathogen to healthy Limonium hybrid seedlings (Table 3 ). Leafhoppers could acquire phytoplasma from infected plants collected from the field in either winter or spring.

\section{Discussion}

Phytoplasmas are transmitted by leafhoppers and planthoppers. Transmission of pathogens by insects, including leafhoppers and planthoppers, depends on the abundance of the vector(s) and their interplant movement (Irwin and Ruesink, 1986; Power, 1987, 1992) and host plant density (Power, 1987, 1992). Limonium seedlings are planted $50 \mathrm{~cm}$ apart and quickly form a continu- ous canopy in each bed, allowing leafhoppers to move easily from one plant to another. Although beds are $1.2 \mathrm{~m}$ apart, the effective distance between plants in adjacent beds is $\approx 50 \mathrm{~cm}$ or less; a distance easily traversed by leafhoppers. In our survey, leafhoppers were trapped throughout the year, except mid-summer. The Arava has a plant-free period in mid-summer when temperatures are about $40^{\circ} \mathrm{C}$ daily and all annual plants are removed; the combined effects of intense heat and reduced host plant numbers severely reduces insect populations.

The abundance of $O$. orientalis was $\approx 10$ times that of any other species caught in this study. It is distributed from the eastern Mediterranean to Japan, and has long been known to vector phytoplasma diseases such as: sesame phyllody in Israel (Klein, 1977) and India (Regupathy and Jayara, 1973); witches' broom disease of legumes in Japan (Ishihara, 1982); and alfalfa witches' broom in Iran (Salehi et al., 1995).

Three other species of leafhopper were trapped in relatively low numbers compared to O. orientalis. Circuliferhaematoceps is a known vector of sesame phyllody in Turkey (Kersting, 1993) and Iran (Salehi and Izadpanah, 1992). Circulifer tenellus is a well-known vector of Spiroplasma citri in the U.S. (Kaloostian et al., 1975) and Israel (Almeida et al., 1997), and of curly-top virus in the U.S. (Gardner and Cannon, 1972), although this is apparently the first record of it vectoring a phytoplasma. Exitianus exitiosus is a known vector of spiroplasmas (Nault, 1980), although this is apparently the first record of $E$. capicola transmitting a phytoplasma.

In 1996, as part of another project, a survey of insect fauna was made in the Arava. A review of that survey material, indicated that all species observed in this study were represented in the 1996 material; that is, the potential vectors were already present in the area before the disease. Close querying of the growers in the Arava revealed that they noticed some diseased plants in 1999, but since very few plants were affected and the disease was not previously known, no management strategies were implemented. Since potential leafhopper vectors were already present in the area, it is not surprising that the disease rapidly spread in 2000. Moreover, in 2000 growers in South America also observed a phytoplasma-type disease in 'Supreme' Limonium hybrids grown in greenhouses from which leafhoppers are excluded. These seedlings, like those in Israel, were imported from California; most probably, this was the source of the phytoplasma. Now that insect vectors of limonium yellows have been identified, research into possible management strategies for the insects and the pathogen is underway.

\section{Literature Cited.}

Almeida, L., B. Raccah, and M. Klein. 1997. Transmission characteristics of Spiroplasma citri and its effect on leafhopper vectors from the Circulifer tenellus complex. Ann. Appl. Biol. 130:49-59.

Font I., P. Abad, M. Albinana, A.I. Espino, E.L. Dally, R.E. Davis, and C. Jorda. 1999. Amarilleos y enrojecimientos en zanahoria: una enfermedad a diagnostico. Bol. de Sanidad Vegetal Plagas 25:405-415.

Gardner, D.E. and O.S. Cannon. 1972. Curly top viruliferous and nonviruliferous leafhopper feeding effects upon tomato seedlings. Phytopathology 62:183-186.

Irwin M.E. and W.G. Ruesink. 1986. Vector intensity: a product of propensity and activity, p. 13-33. In: G.D. McLean, R.G. Garrett, and W.G. Ruesink (eds.). Plant virus epidemics: Monitoring, modelling and predicting outbreaks. Academic Press, New York.

Ishihara, T. 1982. Some notes on a leafhopper of economic importance Orosius orientalis (Matsumura, 1914) (Hemiptera: Cicadellidae). Appl. Entomol. Zool. 17:364-367.

Kaloostian, G.H., G.N. Oldfield, H.D. Pierce, E.C. Calavan, A.L. Granett, G.L. Rana, and D.J. Gumpf. 1975. Leafhopper-Natural vector of citrus stubborn disease? Calif. Agr. 29(2):14-15.

Kersting, U. 1993. Symptomatology, etiology and transmission of sesame phyllody in Turkey. J. Türk. Phytopathol. 22:47-54.

Klein, M. 1977. Sesame phyllody in Israel. Phytopathol. Zeit. 88:165-171.

Lee, I.-M., D.E. Gundersen, R.W. Hammond, and R.E. Davis. 1995. Use of mycoplasmalike organism (MLO) group-specific oligonucleotide primers for nested-PCR assays to detect mixed-MLO infections in a single host plant. Phytopathology 84:559-566.

Maixner, M., U. Ahrens, and E. Seemuller. 1995. Detection of the German grapevine yellows (Vergilbungskrankheit)MLO in grapevine, alternative hosts and a vector by a specific PCR procedure. Euro. J. Plant Pathol. 101:241-250.

Nault, L.R. 1980. Maize bushy stunt and corn stunt: a comparison of disease symptoms, pathogen host ranges, and vectors. Phytopathology 70:659-662.

PowerA.G. 1987. Plant community diversity, herbivore movement, and an insect-transmitted disease of maize. Ecology 68:1658-1669.

Power A.G. 1992. Host plant dispersion, leafhopper movement and disease transmission. Ecol. Entomol. 17:63-68.

Regupathy, A. and S. Jayara. 1973. Physiology of sesamum phyllody disease and its influence on the infestation of the leafhopper vector Orosius albicinctus Dist. Phytopathol. Zeit. 78:86-88.

Salehi, M. and K. Izadpanah. 1992. Etiology and transmission of sesame phyllody in Iran. J. Phytopathol. 135:37-47.

Salehi, M., K.Izadpanah, andF. Ebrahim-Nesbat. 1995. Etiology, transmission and host range of alfalfa witches' broom in southern Iran. Iranian J. Plant Pathol. 31:1-4.

Sambrook, J., E.F. Fritsch, and T. Maniatis. 1989. Molecular cloning. A laboratory manual. 2nd ed. Cold Spring Harbor Laboratory, Cold Spring Harbor, N.Y.

Schneider, B., U. Ahrens, and B.C. Kirkpatrick. 1993. Classification of plant pathogenic mycoplasmalike organisms using restriction site analysis of PCR amplified 16S DNA. J. Gen. Microbiol. 139:519-527.

Tanne, E., L. Kuznetsova, J. Cohen, S. Alexandrov, and A. Gera. 2000. Phytoplasmas as causal agents of celosia diseases in Israel. HortScience 35:103-116. 